\title{
Communication Problems and Quality of Life People with Hearing Loss
}

\author{
Jasenka Broz Frajtag1* and Jagoda Doko Jelinic ${ }^{2}$ \\ ${ }^{1}$ Clinical Hospital Center Zagreb, University of Zagreb \\ ${ }^{2}$ University of Zagreb, School of Medicine
}

Submission: September 11, 2017; Published: September 19, 2017

*Corresponding author: Jasenka Broz Frajtag, Clinical Hospital Center Zagreb, University of Zagreb , ZAGREB, Europe, Tel: 00385992545707.

\begin{abstract}
Introduction: Communication difficulties arising from damage to hearing directly affect quality of life. Difficulties in communication may result in deviations in the emotional and social development and can have a significant impact on the quality of life of every person.

Objective: To evaluate the communication skills and the quality of life of people with hearing impairments with regard to the degree of hearing impairment, as well as social and emotional difficulties they face.

Patients and Methods: The study included 50 patients with hearing loss at the age of 25-55 years who came to regular hearing control at the Clinic for diseases of the ear, nose and throat and head and neck surgery in the period from 2012. to 2015. years. Medical history review, examining the existing medical records and the results of the diagnostic procedures were the general data, the possible cause of hearing damage, when the damage occured, lasting duration, mode of communication in the family and the environment, the quality of life for each subject. Test for the social and emotional difficulties of people with hearing impairments was used HHIa questionnaire, and SF36 questionnaire assessing quality of life.
\end{abstract}

Results: Most of the respondents have hearing loss in both ears, which have been classified as one of the moderate hearing losses. Testing distinction of words frequency and intensity balanced at standard rate showed that most respondents understand the words that are used in everyday communication, the harder they understood the words that contain a group of consonants "dn", "pr" and "št" because the frequency of less frequently used in our language and have relatively low levels of language competence. Self-assessment of quality of life related to health is the worst in the field of health that reflect the vitality, mental health and general health perception. HHIa questionnaire and the social and emotional domain differs significantly individual auditory threshold levels in all of the observed frequencies and in both ears.

Conclusion: Difficulties in communication may result in deviations in the emotional and social development and can have a significant impact on the quality of life of every person. Regular checks of hearing and timely diagnosis contribute to improvement of speech understanding and therefore better functioning in everyday life as a successful factor in resolving further emotional, social and psychological conditions. With modern hearing aids hard of hearing people achieve improvement in speech understanding and a better quality of life. Due to modern lifestyles and the increasing number of factors that can cause hearing loss is necessary to carry out preventive measures to prevent hearing damage.

Keywords: Hearing loss; Communication; Quality of life

\section{Introduction}

Communication difficulties arising from damage to hearing directly affect quality of life. Difficulties in communication may result in deviations in the emotional and social development and can have a significant impact on the quality of life of every person. It is well recognized that hearing is critical to speech and language development, communication, and learning. People with listening difficulties due to hearing loss or auditory processing problems continue to be an underidentified and underserved population. The earlier the problem is identified and intervention begun, the less serious the ultimate impact [1].
Hypothesis: Communication skills and quality of life in people with hearing impairment affect their social and emotional disabilities.

\section{Objective of Investigation}

The aim of this study is to evalute communication skills and quality of life in people with hearing impairent who regularly undergo auditory hearing at the Clinic for Ear, Nose, Throat and Surgery at KBC Zagreb in Zagreb. 


\section{Global Journal of Otolaryngology}

\section{Research Methods}

The study included 50 patients with hearing loss at the age of 25-55 years who came to regular hearing control at the Clinic for diseases of the ear, nose and throat and head and neck surgery in the period from 2012. to 2015. years. Medical history review, examining the existing medical records and the results of the diagnostic procedures was the general data, the possible cause of hearing damage, when the damage occured, lasting duration, mode of communication in the family and the environment, the quality of life for each subject. Test for the social and emotional difficulties of people with hearing impairments was used by HHIA questionnaire, and SF36 questionnaire assessing quality of life [2].

Anamnesis: Otorhinolaryngological examinations are performed using specific aids such as speculum, ear canal, fiberendoscope and otomicroscope (Figure 1).

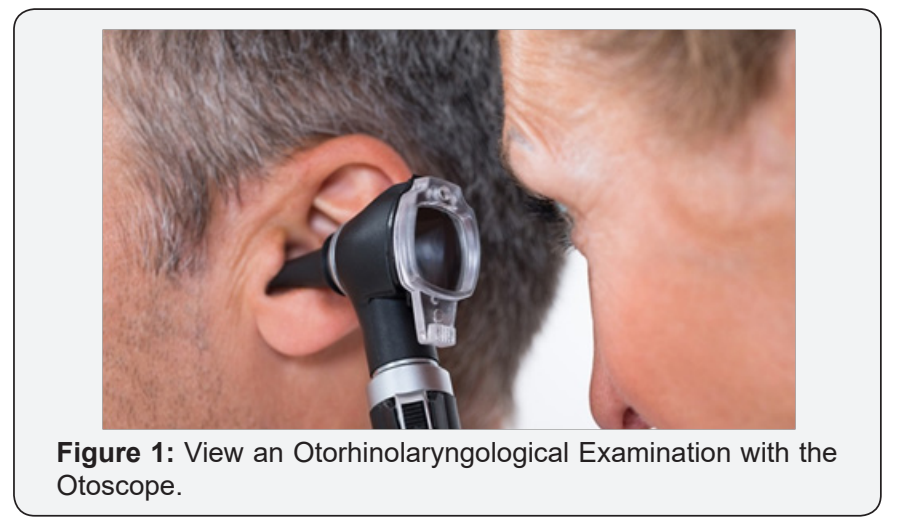

Tonal Audiometry: Hearing condition analysis was performed by a tonal audiometry that determined and compared the average hearing threshold of individual audiometric frequencies at $500 \mathrm{~Hz}$, $1000 \mathrm{HZ}, 2000 \mathrm{~Hz}, 4000 \mathrm{~Hz}, 6000 \mathrm{~Hz}, 8000 \mathrm{~Hz}$. For the right and left ear of each examine (Figure 2).

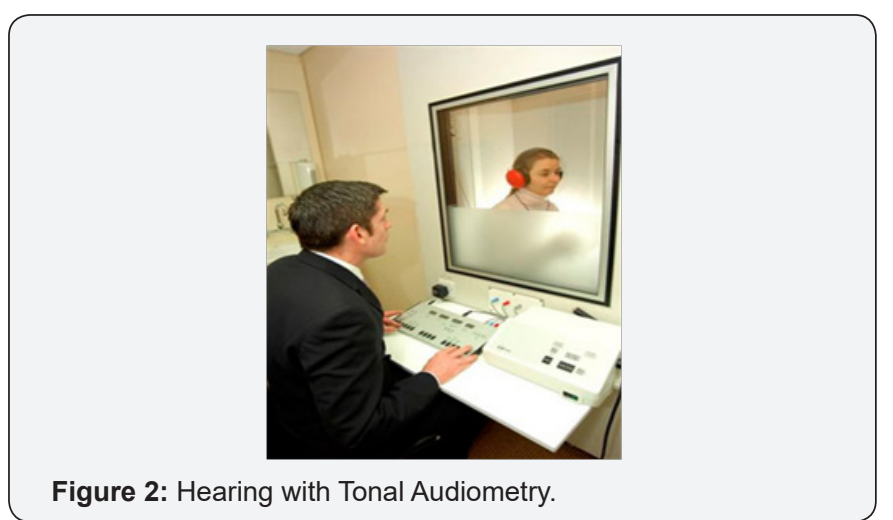

Speech Audiometry: Speech understanding was conducted in a silent, acoustically isolated room where the audiogram measures the percentage of speech scattering in background. In a free field, at a distance of $1 \mathrm{~m}$ from the subject, a word list is played. These commonly included single words (mono- or bisyllabic words), sentences or phonemes (vowels and consonants). It is preferable to assess speech perception in a patient's native language $[3,4]$. A 10 word list is given to the respondent, each of which is estimated at $10 \%$ and is the result of speech audiometry as a percentage understanding. Patientes had to repeat a list of words to determine your Speech Reception Threshold (SRT) and audiologist was measured Speech Discrimination or Word Recognition ability (Figure 3).

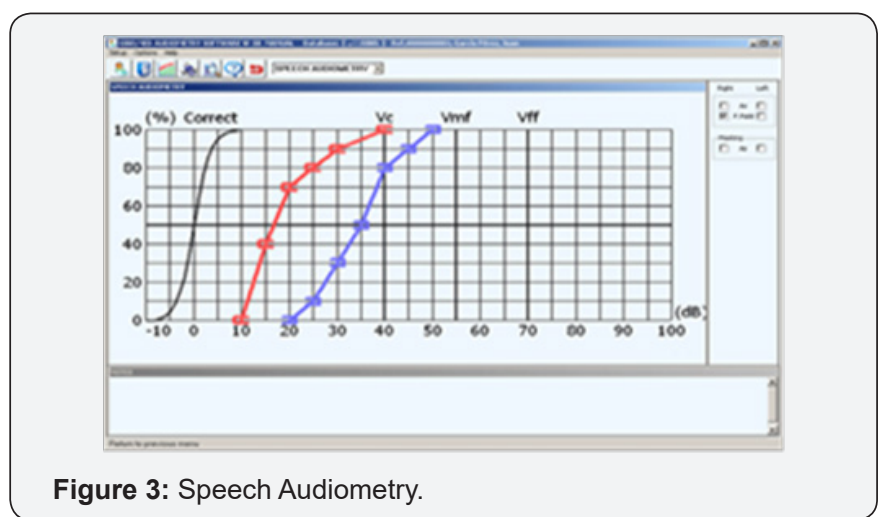

Quality of life of people with hearing loss: The qestionnaire was used for self-assessment of the quality of life associated with health. The data collected by the SF-36 questionnaire are transformed and summarized in a scale of 0 to $100 \%$ for each of the eight dimensions (Physical Functionality, Physical Limitations, Emotional Restrictions, Social Functioning, Mental Health, Energy and Vitality, Pain, general Perception health). Data were analyzed descriptively and presented should read arithmetic means and standar deviations and higher mean values indicate better selfreported health.

Social and emotional disabilities in hearing impaired: The HHIA questionnaire was used to examine social and emotional difficulties in our respondents. The purpose of the scale is to identity hearing loss issues where respondents have to answer every question with "Yes“ , „No“ or "Sometimes“ in situations when they are not using hearing aids (Figure 4).

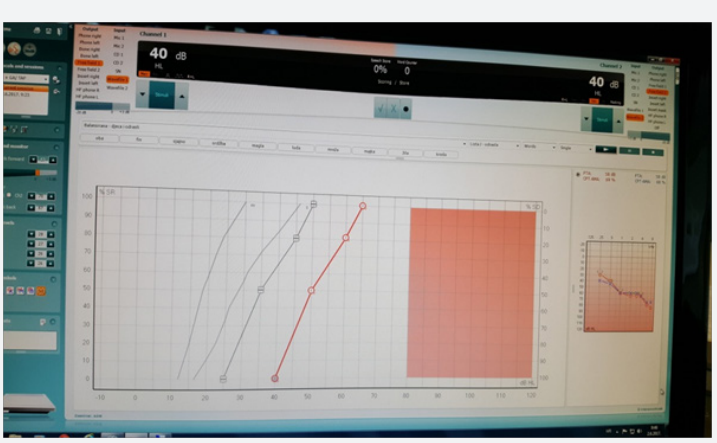

Figure 4: Speech Audiometry Curve in balanced conditions.

\section{Results}

Causes of hearing impairment Anamnestic data shows that among the subjects the most common cause of hearing loss is genetic impairment, than illnesses which include meningitis, otosclerosis, ear inflammation, polyps and viruses. Anamnestic data shows that among the subjects, the most common cause of hearing loss is genetic impairment of hearing in 18 subjects, followed by 


\section{Global Journal of Otolaryngology}

diseases in 15 subjects including meningitis, otosclerosis, ear inflammation, polyps and viruses. Hearing impairment analysis showed occupational hearing impairment in all professions, and the highest percentage of hearing impairment is registered with workers exposed to high levels of noise [5]. Most of the respondents have hearing loss in both ears, which have been classified as one of the moderate hearing losses. Testing distinction of words frequency and intensity balanced at standard rate showed that most respondents understand the words that are used in everyday communication, the harder they understood the words that contain a group of consonants «dn», «pr" and «št» because the frequency of less frequently used in our language and have relatively low levels of language competence.

Self-assessment of quality of life related to health is the worst in the field of health that reflect the vitality, mental health and general health perception. HHIA questionnaire and the social and emotional domain differs significantly individual auditory threshold levels in all of the observed frequencies and in both ears. The cause of hearing impairment of the respondents who were exposed to high levels of work during the workplace was 9 and the injures cause hearing impairment in 2 [6]. Hearing impairment analysis showed occupational hearing impairment in professions and the highest percentage is registered with workers exposed to high noise levels. Moderate hearing loss was the most common hearing impairment among respondents and the least represented among respondents was severe hearing loss. Speech understanding show that most respondents have better understanding of the words they use in communication everyday than those less used.

Quality of life of people with hearing loss: In the total sample of two dimensions of health that describe physical function and limitation for emotional problems, the average values were above $70 \%$, while lower average values were measured for health dimensions that describe vitality, mental health and perception of general health ranging from $51,00 \%$ to $54,04 \%$ [7-11] .

Social and emotional disabilities in hearing impaired: The HHIA questionnaire was used to examine social and emotional difficulties in our respondents. The analysis of responses to the social domain ( yes, sometimes, no) of the questionnaires collected showed that $13(26,0 \%)$ of the respondents did not have a handicap, the moderate handicap had $17(34,0 \%)$, while the pronounced handicap had $20(40,0 \%)$. For the emotional domain, the HHIA questionaire analysis showed that the smallest number of respondents showed significant handicap 15 / 30,0 \%) and 19 $(38,0 \%)$ respondents without handicap (Table 1$)$. The analysis of questions related to the HHIA social domain has shown that the highest handicap has the highest number of $\mathrm{N}=20$, while the largest number of $\mathrm{N}=19$ disabled is on the emotional domain (Tables 2 \& 3). Table 3.shows no significant differences between SF-36 domain and HHIA social domain and emotional domain (Table 4).

Table 1: Social and emotional difficulties in hearing impaired respondents to HHIA questionnaire.

\begin{tabular}{|c|c|c|c|}
\hline & & $\mathbf{N}$ & $\%$ \\
\hline \multirow{3}{*}{ HHIA social domain } & Without handicap & 13 & $26,0 \%$ \\
\hline & Moderate handicap & 17 & $34,0 \%$ \\
\hline & Severe handicap & 20 & $40,0 \%$ \\
\hline \multirow{3}{*}{ HHIA emotional domain } & Without handicap & 19 & $38,0 \%$ \\
\hline & Moderate handicap & 16 & $32,0 \%$ \\
\hline & Severe handicap & 15 & $30,0 \%$ \\
\hline \multirow{3}{*}{ HHIA summary } & Without handicap & 16 & $32,0 \%$ \\
\hline & Moderate handicap & 16 & $32,0 \%$ \\
\hline & Severe handicap & 18 & $36,0 \%$ \\
\hline
\end{tabular}

Table 2: Descriptive statistics of respondents with regard to category variables $(N=50)$.

\begin{tabular}{|c|c|c|c|c|c|c|c|}
\hline & $\begin{array}{c}\text { Arithmetic } \\
\text { mean }\end{array}$ & SD & Min & Max & \multicolumn{2}{|c|}{ Centil } \\
\cline { 5 - 7 } Age & 46,2 & 8,5 & 30,0 & 62,0 & 37,8 & 48,0 & 53,0 \\
\hline $\begin{array}{c}\text { Disease } \\
\text { duration(y) }\end{array}$ & 7,3 & 9,4 & 0,3 & 44,0 & 1,0 & 5,0 & 10,0 \\
\hline $\begin{array}{c}\text { Right ear 500 Hz } \\
\text { (dB) }\end{array}$ & 41,5 & 26,5 & 10,0 & 95,0 & 20,0 & 37,5 & 65,0 \\
\hline $\begin{array}{c}\text { Right ear 1000 } \\
\text { Hz (dB) }\end{array}$ & 49,7 & 27,8 & 10,0 & 100,0 & 30,0 & 47,5 & 75,0 \\
\hline $\begin{array}{c}\text { Right ear 2000 } \\
\text { Hz (dB) }\end{array}$ & 53,9 & 28,3 & 10,0 & 100,0 & 35,0 & 55,0 & 80,0 \\
\hline $\begin{array}{c}\text { Right ear 4000 } \\
\text { Hz (dB) }\end{array}$ & 60,8 & 30,2 & 10,0 & 110,0 & 38,8 & 62,5 & 90,0 \\
\hline
\end{tabular}




\begin{tabular}{|c|c|c|c|c|c|c|c|}
\hline $\begin{array}{c}\text { Right ear 6000 } \\
\mathrm{Hz}(\mathrm{dB})\end{array}$ & 66,3 & 30,5 & 10,0 & 110,0 & 45,0 & 70,0 & 90,0 \\
\hline $\begin{array}{c}\text { Right ear 8000 } \\
\mathrm{Hz}(\mathrm{dB})\end{array}$ & 66,1 & 32,1 & 10,0 & 110,0 & 45,0 & 67,5 & 90,0 \\
\hline $\begin{array}{c}\text { Left ear 500 Hz } \\
\text { (dB) }\end{array}$ & 43,0 & 26,5 & 10,0 & 100,0 & 20,0 & 52,5 & 50,0 \\
\hline $\begin{array}{c}\text { Left ear 1000 Hz } \\
\text { (dB) }\end{array}$ & 49,9 & 27,0 & 10,0 & 110,0 & 35,0 & 57,5 & 80,0 \\
\hline $\begin{array}{c}\text { Left ear 2000 Hz } \\
\text { (dB) }\end{array}$ & 54,7 & 28,8 & 10,0 & 110,0 & 28,8 & 65,0 & 86,3 \\
\hline $\begin{array}{c}\text { Left ear 4000 } \\
\text { Hz (dB) }\end{array}$ & 61,4 & 28,9 & 10,0 & 110,0 & 42,5 & 75,0 & 95,0 \\
\hline $\begin{array}{c}\text { Left ear 6000 } \\
\text { Hz (dB) }\end{array}$ & 72,3 & 29,1 & 15,0 & 110,0 & 55,0 & 70,0 & 95,0 \\
\hline $\begin{array}{c}\text { Left ear 8000 } \\
\text { Hz (dB) }\end{array}$ & 69,4 & 30,0 & 10,0 & 110,0 & 55,0 & 35,0 \\
\hline $\begin{array}{c}\text { Sound detection } \\
\text { threshold }\end{array}$ & 35,3 & 16,8 & 5,0 & 75,0 & 23,8 & 62,5 & 65,0 \\
\hline $\begin{array}{c}100 \% \text { speech } \\
\text { understanding }\end{array}$ & 52,8 & 17,7 & 15,0 & 85,0 & 37,5 & 65 \\
\hline
\end{tabular}

Table 3: Interaction of SF-36 Individuals domains and HHIA social domain: Kruskal-Wallis Test.

\begin{tabular}{|c|c|c|c|c|c|c|}
\hline & & & & Centile & & \\
\hline & & & 25 & Mediian & 75 & \\
\hline & Without handicap & 13 & 57,50 & 90,00 & 95,00 & 0,678 \\
\hline $\begin{array}{l}\text { SF-36: Physical } \\
\text { functioning }\end{array}$ & Moderate handicap & 17 & 52,50 & 70,00 & 100,00 & \\
\hline & Severe handicap & 20 & 60,00 & 65,00 & 85,00 & \\
\hline & Without handicap & 13 & 0,00 & 75,00 & 100,00 & 0,163 \\
\hline $\begin{array}{l}\text { SF-36: Limitations } \\
\text { of physical } \\
\text { problems }\end{array}$ & $\begin{array}{l}\text { Moderate } \\
\text { handicap }\end{array}$ & 17 & 75,00 & 75,00 & 100,00 & \\
\hline & Severe handicap & 20 & 25,00 & 50,00 & 100,00 & \\
\hline & Without handicap & 13 & 50,00 & 100,00 & 100,00 & 0,880 \\
\hline $\begin{array}{l}\text { SF-36: Limitations } \\
\text { of emtional }\end{array}$ & $\begin{array}{l}\text { Moderate } \\
\text { handicap }\end{array}$ & 17 & 50,00 & 100,00 & 100,00 & \\
\hline & Severe handicap & 20 & 33,33 & 100,00 & 100,00 & \\
\hline & Without handicap & 13 & 43,75 & 62,50 & 75,00 & 0,506 \\
\hline $\begin{array}{l}\text { SF-36: Socijal } \\
\text { functioning }\end{array}$ & $\begin{array}{l}\text { Moderate } \\
\text { handicap }\end{array}$ & 17 & 50,00 & 62,50 & 68,75 & \\
\hline & Severe handicap & 20 & 50,00 & 56,25 & 62,50 & \\
\hline & Without handicap & 13 & 48,00 & 52,00 & 62,00 & 0,975 \\
\hline $\begin{array}{l}\text { SF-36: Mental } \\
\text { health }\end{array}$ & $\begin{array}{l}\text { Moderate } \\
\text { handicap }\end{array}$ & 17 & 46,00 & 52,00 & 56,00 & \\
\hline & Severe handicap & 20 & 44,00 & 52,00 & 59,00 & \\
\hline & Without handicap & 13 & 47,50 & 55,00 & 60,00 & 0,250 \\
\hline $\begin{array}{l}\text { SF-36: Energy and } \\
\text { vitality }\end{array}$ & $\begin{array}{l}\text { Moderate } \\
\text { handicap }\end{array}$ & 17 & 47,50 & 50,00 & 57,50 & \\
\hline & Severe handicap & 20 & 45,00 & 50,00 & 50,00 & \\
\hline & Without handicap & 13 & 55,00 & 70,00 & 80,00 & 0,376 \\
\hline SF-36: Pains & $\begin{array}{l}\text { Moderate } \\
\text { handicap }\end{array}$ & 17 & 30,00 & 50,00 & 60,00 & \\
\hline & Severe handicap & 20 & 42,50 & 60,00 & 70,00 & \\
\hline
\end{tabular}


Global Journal of Otolaryngology

\begin{tabular}{|c|c|c|c|c|c|c|}
\hline \multirow{2}{*}{$\begin{array}{c}\text { SF-36: General } \\
\text { perception of } \\
\text { health }\end{array}$} & Withouthandicap & 13 & 44,50 & 57,00 & 74,50 & 0,778 \\
\cline { 2 - 7 } & $\begin{array}{c}\text { Moderate } \\
\text { handicap }\end{array}$ & 17 & 46,00 & 52,00 & 54,50 & \\
\cline { 2 - 7 } & Severe handicap & 20 & 47,00 & 52,00 & 55,75 & \\
\hline
\end{tabular}

Table 4: Interaction between SF-36 and HHIA emotional domains: Kruskal-Wallis test.

\begin{tabular}{|c|c|c|c|c|c|c|}
\hline \multirow{2}{*}{\multicolumn{2}{|c|}{ HHIA emotional domain }} & \multirow{3}{*}{$\begin{array}{l}\mathbf{N} \\
19\end{array}$} & \multicolumn{3}{|c|}{ Centil } & \multirow{3}{*}{$\begin{array}{c}\mathbf{P} \\
0,461\end{array}$} \\
\hline & & & \multirow{2}{*}{$\begin{array}{c}25 . \\
60,00\end{array}$} & \multirow{2}{*}{$\begin{array}{c}\text { Medijan } \\
75,00\end{array}$} & \multirow{2}{*}{$\begin{array}{c}75 . \\
90,00\end{array}$} & \\
\hline \multirow{3}{*}{$\begin{array}{l}\text { SF-36: Physical } \\
\text { functioning }\end{array}$} & Without handicap & & & & & \\
\hline & $\begin{array}{l}\text { Moderate } \\
\text { handicap }\end{array}$ & 16 & 52,50 & 77,50 & 100,00 & \\
\hline & Severe handicap & 15 & 55,00 & 65,00 & 85,00 & \\
\hline \multirow{3}{*}{$\begin{array}{l}\text { SF-36: Limitations } \\
\text { of physical } \\
\text { problems }\end{array}$} & Without handicap & 19 & 0,00 & 75,00 & 100,00 & 0,759 \\
\hline & $\begin{array}{l}\text { Moderate } \\
\text { handicap }\end{array}$ & 16 & 31,25 & 75,00 & 100,00 & \\
\hline & Severe handicap & 15 & 25,00 & 75,00 & 100,00 & \\
\hline \multirow{3}{*}{$\begin{array}{l}\text { SF-36: Limitations } \\
\text { of emtional } \\
\text { problems }\end{array}$} & Without handicap & 19 & 66,67 & 100,00 & 100,00 & 0,421 \\
\hline & $\begin{array}{l}\text { Moderate } \\
\text { handicap }\end{array}$ & 16 & 8,33 & 66,67 & 100,00 & \\
\hline & Severe handicap & 15 & 33,33 & 100,00 & 100,00 & \\
\hline \multirow{3}{*}{$\begin{array}{l}\text { SF-36: Socijal } \\
\text { functioning }\end{array}$} & Without handicap & 19 & 37,50 & 62,50 & 75,00 & 0,694 \\
\hline & $\begin{array}{l}\text { Moderate } \\
\text { handicap }\end{array}$ & 16 & 50,00 & 62,50 & 62,50 & \\
\hline & Severe handicap & 15 & 50,00 & 62,50 & 75,00 & \\
\hline \multirow{3}{*}{$\begin{array}{l}\text { SF-36: Mental } \\
\text { health }\end{array}$} & Without handicap & 19 & 48,00 & 52,00 & 60,00 & 0,748 \\
\hline & $\begin{array}{l}\text { Moderate } \\
\text { handicap }\end{array}$ & 16 & 45,00 & 52,00 & 56,00 & \\
\hline & Severe handicap & 15 & 44,00 & 48,00 & 56,00 & \\
\hline \multirow{3}{*}{$\begin{array}{l}\text { SF-36: Energy and } \\
\text { vitality }\end{array}$} & Without handicap & 19 & 45,00 & 50,00 & 55,00 & 0,550 \\
\hline & $\begin{array}{l}\text { Moderate } \\
\text { handicap }\end{array}$ & 16 & 50,00 & 50,00 & 58,75 & \\
\hline & Severe handicap & 15 & 50,00 & 50,00 & 50,00 & \\
\hline \multirow{3}{*}{ SF-36: Pains } & Without handicap & 19 & 40,00 & 70,00 & 70,00 & 0,685 \\
\hline & $\begin{array}{l}\text { Moderate } \\
\text { handicap }\end{array}$ & 16 & 50,00 & 60,00 & 67,50 & \\
\hline & Severe handicap & 15 & 40,00 & 60,00 & 60,00 & \\
\hline \multirow{3}{*}{$\begin{array}{l}\text { SF-36: General } \\
\text { perception of } \\
\text { health }\end{array}$} & Without handicap & 19 & 47,00 & 57,00 & 67,00 & 0,838 \\
\hline & $\begin{array}{l}\text { Moderate } \\
\text { handicap }\end{array}$ & 16 & 45,50 & 52,00 & 52,00 & \\
\hline & Severe handicap & 15 & 45,00 & 52,00 & 57,00 & \\
\hline
\end{tabular}

Statistically significant differences are not associated with at all observed frequencies and on both ears (Table 5). HHIA the SF-36 and the social and emotional domains of HHIA (Tables 3 questionnaire in its emotional domain significantly differentiates \& 4). Analysis of the results obtained with the HHIA questionnaire the individual auditory levels at all observed frequencies and on shows that the HHIA questionnaire in its social domain significantly both ear (Table 6). differentiates the individual's levels of the auditory threshold 


\section{Global Journal of Otolaryngology}

Table 5: Differences in the level of hearing thresholds of the social handicapped by an estimated HHIA questionnaire.

\begin{tabular}{|c|c|c|c|c|c|}
\hline \multicolumn{2}{|c|}{ HHIA social } & \multirow{2}{*}{$\begin{array}{c}\text { Medijan } \\
10,0 \\
\end{array}$} & \multirow{2}{*}{$\begin{array}{c}\text { 25. centil } \\
10,0 \\
\end{array}$} & \multirow{2}{*}{$\begin{array}{c}\text { 75. centil } \\
40,0 \\
\end{array}$} & \multirow{2}{*}{$\begin{array}{c}\mathbf{P} \\
0,003\end{array}$} \\
\hline r500 & Without handicap & & & & \\
\hline & Moderate handicap & 35,0 & 30,0 & 45,0 & \\
\hline & Severe handicap & 55,0 & 25,0 & 80,0 & \\
\hline \multirow[t]{3}{*}{ r1000 } & Without handicap & 10,0 & 10,0 & 45,0 & 0,001 \\
\hline & Moderate handicap & 45,0 & 30,0 & 65,0 & \\
\hline & Severe handicap & 72,5 & 42,5 & 85,0 & \\
\hline \multirow[t]{3}{*}{ r2000 } & Without handicap & 15,0 & 10,0 & 50,0 & 0,001 \\
\hline & Moderate handicap & 50,0 & 40,0 & 65,0 & \\
\hline & Severe handicap & 77,5 & 50,0 & 87,5 & \\
\hline \multirow[t]{3}{*}{ r6000 } & Without handicap & 35,0 & 20,0 & 60,0 & 0,001 \\
\hline & Moderate handicap & 70,0 & 50,0 & 85,0 & \\
\hline & Severe handicap & 82,5 & 60,0 & 100,0 & \\
\hline \multirow[t]{3}{*}{ r8000 } & Without handicap & 30,0 & 10,0 & 55,0 & 0,001 \\
\hline & Moderate handicap & 65,0 & 50,0 & 90,0 & \\
\hline & Severe handicap & 87,5 & 67,5 & 105,0 & \\
\hline \multirow[t]{3}{*}{$\mathrm{r} 4000$} & Without handicap & 20,0 & 10,0 & 50,0 & 0,001 \\
\hline & Moderate handicap & 70,0 & 60,0 & 80,0 & \\
\hline & Severe handicap & 82,5 & 55,0 & 92,5 & \\
\hline \multirow[t]{3}{*}{1500} & Without handicap & 10,0 & 10,0 & 35,0 & 0,004 \\
\hline & Moderate handicap & 40,0 & 35,0 & 50,0 & \\
\hline & Severe handicap & 52,5 & 35,0 & 82,5 & \\
\hline \multirow[t]{3}{*}{11000} & Without handicap & 15,0 & 10,0 & 40,0 & $<0,001$ \\
\hline & Moderate handicap & 50,0 & 35,0 & 65,0 & \\
\hline & Severe handicap & 65,0 & 50,0 & 80,0 & \\
\hline \multirow[t]{3}{*}{12000} & Without handicap & 20,0 & 10,0 & 25,0 & $<0,001$ \\
\hline & Moderate handicap & 55,0 & 40,0 & 65,0 & \\
\hline & Severe handicap & 70,0 & 62,5 & 87,5 & \\
\hline \multirow[t]{3}{*}{14000} & Without handicap & 20,0 & 10,0 & 45,0 & $<0,001$ \\
\hline & Moderate handicap & 70,0 & 45,0 & 85,0 & \\
\hline & Severe handicap & 72,5 & 62,5 & 92,5 & \\
\hline \multirow[t]{3}{*}{1600} & Without handicap & 25,0 & 20,0 & 75,0 & $<0,001$ \\
\hline & Moderate handicap & 75,0 & 65,0 & 95,0 & \\
\hline & Severe handicap & 90,0 & 72,5 & 97,5 & \\
\hline \multirow[t]{3}{*}{18000} & Without handicap & 35,0 & 15,0 & 70,0 & $<0,001$ \\
\hline & Moderate handicap & 70,0 & 55,0 & 90,0 & \\
\hline & Severe handicap & 85,0 & 67,5 & 97,5 & \\
\hline \multirow[t]{3}{*}{$\begin{array}{l}\text { Sound detection } \\
\text { threshold }\end{array}$} & Without handicap & 10,0 & 10,0 & 35,0 & $<0,001$ \\
\hline & Moderate handicap & 35,0 & 30,0 & 40,0 & \\
\hline & Severe handicap & 45,0 & 37,5 & 55,0 & \\
\hline \multirow[t]{3}{*}{$\begin{array}{l}100 \% \text { speech } \\
\text { understanding }\end{array}$} & Without handicap & 30,0 & 25,0 & 62,5 & 0,024 \\
\hline & Moderate handicap & 65,0 & 55,0 & 65,0 & \\
\hline & Severe handicap & 65,0 & 50,0 & 70,0 & \\
\hline
\end{tabular}




\section{Global Journal of Otolaryngology}

Table 6:Hearing threshold differences in relation to the type of emotional handicap estimated by the HHIA questionnaire: Kruskal-Wallis test.

\begin{tabular}{|c|c|c|c|c|c|}
\hline & & HHIA SOc & & & $\mathbf{P}$ \\
\hline & & Medijan & 25. centila & 75. centila & \\
\hline r500 & without handicap & 20,0 & 10,0 & 45,0 & 0,002 \\
\hline & moderate handicap & 35,0 & 25,0 & 47,5 & \\
\hline & severe handicap & 65,0 & 40,0 & 80,0 & \\
\hline r1000 & without handicap & 25,0 & 10,0 & 50,0 & 0,001 \\
\hline & moderate handicap & 45,0 & 35,0 & 70,0 & \\
\hline & severe handicap & 75,0 & 50,0 & 85,0 & \\
\hline r2000 & without handicap & 35,0 & 10,0 & 60,0 & 0,001 \\
\hline & moderate handicap & 52,5 & 42,5 & 77,5 & \\
\hline & severe handicap & 80,0 & 55,0 & 90,0 & \\
\hline r6000 & without handicap & 45,0 & 25,0 & 70,0 & 0,004 \\
\hline & moderate handicap & 82,5 & 57,5 & 102,5 & \\
\hline & severe handicap & 80,0 & 65,0 & 100,0 & \\
\hline r8000 & without handicap & 45,0 & 15,0 & 65,0 & 0,001 \\
\hline & moderate handicap & 75,0 & 60,0 & 102,5 & \\
\hline & without handicap & 85,0 & 65,0 & 110,0 & \\
\hline r4000 & without handicap & 20,0 & 10,0 & 50,0 & 0,001 \\
\hline & moderate handicap & 70,0 & 60,0 & 80,0 & \\
\hline & severe handicap & 82,5 & 55,0 & 92,5 & \\
\hline 1500 & without handicap & 20,0 & 10,0 & 50,0 & 0,002 \\
\hline & moderate handicap & 40,0 & 35,0 & 47,5 & \\
\hline & severe handicap & 55,0 & 45,0 & 85,0 & \\
\hline 11000 & without handicap & 35,0 & 10,0 & 45,0 & $<0,001$ \\
\hline & moderate handicap & 50,0 & 35,0 & 75,0 & \\
\hline & severe handicap & 70,0 & 50,0 & 80,0 & \\
\hline 12000 & without handicap & 25,0 & 10,0 & 50,0 & 0,001 \\
\hline & moderate handicap & 65,0 & 50,0 & 75,0 & \\
\hline & severe handicap & 70,0 & 60,0 & 95,0 & \\
\hline 14000 & without handicap & 35,0 & 10,0 & 60,0 & 0,001 \\
\hline & moderate handicap & 67,5 & 62,5 & 87,5 & \\
\hline & severe handicap & 85,0 & 60,0 & 95,0 & \\
\hline 16000 & without handicap & 55,0 & 20,0 & 75,0 & $<0,001$ \\
\hline & moderate handicap & 85,0 & 70,0 & 102,5 & \\
\hline & severe handicap & 90,0 & 70,0 & 100,0 & \\
\hline 18000 & without handicap & 45,0 & 20,0 & 70,0 & $<0,001$ \\
\hline & moderate handicap & 80,0 & 60,0 & 95,0 & \\
\hline & severe handicap & 85,0 & 70,0 & 110,0 & \\
\hline Sound detection & without handicap & 15,0 & 10,0 & 35,0 & $<0,001$ \\
\hline & moderate handicap & 35,0 & 27,5 & 40,0 & \\
\hline & severe handicap & 50,0 & 40,0 & 55,0 & \\
\hline $100 \% \quad$ speech & without handicap & 45,0 & 30,0 & 65,0 & 0,022 \\
\hline understanding & moderate handicap & 65,0 & 50,0 & 65,0 & \\
\hline & severe handicap & 67,5 & 65,0 & 70,0 & \\
\hline
\end{tabular}




\section{Global Journal of Otolaryngology}

\section{Discussion}

Hearing loss is the common problem in all ages and represents a significant medical-social problem. Hearing impairment directly affects the quality of life and is the most often manifasted in communication difficulties that can result in deviations in emotional and social development. Of the 32,432 persons who had undergone hearing impairment of hearing loss for five years were found in 4,356 (13,43\%) of the respondents. Among the subjects with some form of hearing loss was slightly higher number of males $\mathrm{N}=2,300$ than women $\mathrm{N}=2,056$. According to the data of the registry of persons with did abilities in the Republic of Croatia living 13609 persond with the cause of hearing impairment and is more common in males 8,047 compared to woman 5,562 . The prevalence of hearing loss in the world according to WHO data is over $5 \%$ and includes 360 million people, whom 328 million adults. The largest numbers of people with disabilities have their permanent residence in the City of Zagreb and in the City of Split.

The results of Speech audiometry used to examine the frequency of speech frequency, showed better results in words which they used every day. The list of words followed by the height of the voice- for example: the voice, which is a very high voice, gives a certain weight of words (word „smoking“), while the word "wine" is classifield into the category of light words. It was difficult to understand words with consonats "d, p,r,t ", because some of that words are rarely used in our language. The main problems people with hearing loss are communication problems that can result in deviations in the quality of life as confirmed among our respondents. Such persons have cognitive and social disabilities in the form of irritability, tension, stress, feelings, and often depression and feelings of loneliness. Hearing loss affects the individual but also his family. It has been repeatedly shown that any inability has a significant stress potential for other members, although any illness or disability is a unique challenge.

Comparison of the results of the self- assessment of he quality of life obtained by the SF-36 questionnaire among our respondents similar to the quality of life compared to the results obtained on the population of the Republic of Croatia in all domains expect in the domains of social functioning and mental health. The questionnaire HHIA is used to examine the social and emotional disabilities in the hearing impaired person, which based on the responses found, identifies the problems of mild to moderate or pronounced hearing loss. HHIA anlysis obtained among our respondents shows that social domain significantly differentiates the individual levels of the auditory threshold at all observed frequencies and on both ears. HHIA anlysis obtained among our respondents shows that emotional domain significantly differentiates the individual auditory levels at all observed frequencies as well as on both ears.

HHIA domain correlates significantly with all examined parameters (frequencies), while SF-36 domains do not correlate significantly with either. Analysis of the answers obtained from the
HHIA questionnaire, referring to the social domain, showed that 13 respondents did not have a handicap; a moderate handicap had 17 respondents, while the pronounced handicap had 20 respondents. For the emotional domain, the analysis of responses showed that the smallest number of respondents 15 showed a marked handicap while without a handicap 19 respondents.

Hearing impairment due to lack of accumulation during life is growing daily, which will result in an increase in the population of hearing impairment. Diagnostic and diagnosis is important for defining the cause and prognosis of the disease, but the function restriction information is often used in planning the intervention. After detailed audiological processing, we are quite confident in the existance, type and strength of hearing impairment and can begin functional therapy for all patients who have hearing problems and those who have hearing aids. People who have hearing aids show improvements in interpersonal communication, reduced anger and frustration. Such results lead to an improvement in the quality of life of hearing impaired people as well as communication programs such as hearing aid rehabilitation programs that seem to have good potential for reducing activity limitations and better quality of life.

\section{Conclusion}

Difficulties in communication may result in deviations in the emotional and social development and can have a significant impact on the quality of life of every person. Regular checks of hearing and timely diagnosis contribute to improvement of speech understanding and therefore better functioning in everyday life as a successful factor in resolving further emotional, social and psychological conditions. With modern hearing aids hard of hearing people achieve improvement in speech understanding and a better quality of life. Anlysis of the answers obtained from the HHIA questionnaire, referring to the social domain, showed that 13 respondents did not have a handicap, the moderate handicap had 17 respondents, while the pronounced handicap had 20 respondents. For the emtional domain, the analysis of responses showed that the smallest number of respondents showed a marked handicap 15 while without a handicap 19 respondents. SF-36 showed that health dimensions that describe physical function and limitation for the most rated emotional problems, while the worst rated health dimensions describing vitality, mental health, and perception of the general Health. This results can contribute to further research on improving the quality of life and well-being vulnerable populations. We believe to include more numbers in this research, these differences were more pronounced and possibly more significant.

\section{References}

1. Aras I, Stevanović R, Vlahović S (2014) Health related quality of life in parents of children with speech and hearing impairment. Pediatric Otorhinolaryngology 78(2): 323-329.

2. Newton VE (2009) Paediatric Audiological Medicine. University of Manchester. 
3. Jusczyk PW (2002) Some critical developments in acquiring native language sound organization during the first year. Ann Otol Rhinol Laryngol 111: 11-15.

4. Maslić Seršić D, Vuletić G (2006) psihometrijskih Evaluacija i uspostavljanje normi hrvatskog SF-36 Health Survey: Okvir za subjektivnog Health Research. Croat Med J 47(1): 95-102.

5. Dalton DS, Cruickshanks KJ (2003) The impact of hearing loss on quality of life in older adults. The Gerontological Society of America 43(5): 661-668.

6. Dobie RA, Van Hemel S (2009) Hearing Loss: Determining Eligibility for Social Security Benefits. National Research Council (US) Committee on Disability Determination for Individuals with Hearing Impairments. Washington. J Speech Lang Hear Res 52(4): 973-989.

7. Hallberg LR, Hallberg U (2008) Self-reported hearing difficulties, communication strategies and psychological general well-being (quality of life) in patients with acquired hearing impairment. Interdisciplinary disability studies 30(3): 203-212.

8. Perlmutter MS, Bhorade A (2010) Cognitive, visual, auditory, and emotional factors that affect participation in older adults. Am J Occup Ther 64(4): 570-579.

9. Genther DJ, Betz J (2015) Association of Hearing Impairment and Mortality in Older Adults. Health ABC Study. J Gerontol A Biol Sci Med Sci 70(1): 85-90.

10. Rand DC (2010) Socioeconomic Status, Family Processes, and Individual Development Family Research Group, Human \& Community Development. University of California 72(3): 685-704.

11. Herman R, Morgan G (2010) Deafness, Language and Communication The Impact of communication Disability across the Lifespan. City University London.UK, pp101-121.

\section{Your next submission with Juniper Publishers will reach you the below assets}

- Quality Editorial service

- Swift Peer Review

- Reprints availability

- E-prints Service

- Manuscript Podcast for convenient understanding

- Global attainment for your research

- Manuscript accessibility in different formats ( Pdf, E-pub, Full Text, Audio)

- Unceasing customer service

Track the below URL for one-step submission https://juniperpublishers.com/online-submission.php 